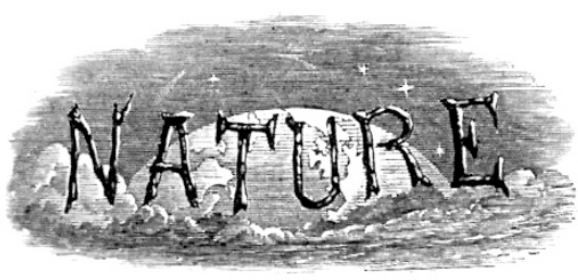

SATURDAY, APRIL 27, 1929.

\title{
CONTENTS.
}

PAGE

The Smithsonian Institution and Scientific Education 629 Science and Humanism

Srinivasa Ramanujan. By Prof. J. E. Littlewood, F.R.S.

Filterable Viruses. By Dr. J. Henderson Smith

Problems of Island Life. By Dr. A. D. Imms

Methods of Sea-water Biology

Our Bookshelf

Letters to the Editor:

The Nature of the Penetrating Radiation.Dr. W. Bothe and Prof. W. Kolhörster .

Temperature Conditions in the Suez Canal, July-December 1928.-R. S. Wimpenny

Anti-Knock Ratings of Pure Hydrocarbons.S. F. Birch and R. Stansfield; Prof. A. W. Nash and Donald A. Howes

Rise and Fall of the Tides.-A. Mallock, F.R.S.

Evolution through Adaptation.-Prof. J. S. Dunkerly ; Dr. F. A. Bather, F.R.S.

The Fine Structure of the Normal Scattered Molybdenum $\mathrm{Ka}$-Radiation from Graphite.Prof. D. Coster, I. Nitta, and W. J. Thijssen .

Variation of Conductivity of the Upper Atmosphere.-J. Egedal

A Violation of the Selection Principle for the Principal Quantum Number.--Sakae Idei

Combustion of Rigidly Dried Carbonic OxideOxygen Mixtures.-Prof. William A. Bone, F.R.S.

Titanium Oxide Bands in the Orange, Red, and Infra-Red Region.-F. Lowater

Ozone Absorption during Long Arctic Night.Prof. R. W. Wood, For. Mem. R.S.

Lengthened Chain Compounds of Sulphur with Platinum.-Sir P. C. Rây

Science and Hypothesis. By Sir Oliver Lodge, F.R.S The Supply and Therapeutic Uses of Radium. By Prof. S. Russ

Obituary :

Sir George Knibbs, C.M.G.

Sir Henry Rew, K.C.B.

Mr. C. E. Benham

Prof, F. Kehrmann

News and Views.

Our Astronomical Column

Research Items

Mimicry. By Dr. G. D. Hale Carpenter

Diamond Jubilee of the Iron and Steel Institute

The Stone Age in South-Eastern Asia

University and Educational Intelligence

Calendar of Patent Records

Societies and Academies

Official Publications Received

Diary of Societies

Recent Scientific and Technical Books
630

631

633

634

635

636

638

638

639

640

641

642

642

643

644

644

644

644

645

648

650

650

651

651

652

657

658

661

663

664

664

665

665

667

667

Supp. vii
Editorial and Publishing Offices:

MACMILLAN \& CO., LTD.,

ST. MARTIN'S STREET, LONDON, W.C. 2

\section{The Smithsonian Institution and Scientific Education.}

YINCE the last Report of the Smithsonian

Institution was published, a new secretary, Dr. Charles G. Abbot, Director of the Astrophysical Observatory, has been appointed, and the Report to June 30,1928 , appears over his signature. It is impossible in these columns to mention, far less to do justice to, the manifold activities of this wonderful institution, with its great museums of science and of art, its zoological park, its astronomical observatory, and its international exchange service. But the new secretary, in virtue of his appointment, has felt it to be his duty to make a wide survey of the activities of "the Smithsonian," in order to gain some knowledge of the most effective ways in which it may advance the mission of its founder, James Smithson, "for the increase and diffusion of knowledge amongst men."

Dr. Abbot's conclusions are of great interest, and since they are of general application, deserve wide attention. He points out that, to the casual observer, it may appear that the most important function of the Smithsonian is the administration of the national museum, art galleries, and zoological park confided to its direction. The educational value of these is great, but a closer analysis would show that their influence is largely confined to the neighbouring States, and that a lessening of influence, which increases rapidly with distance, affects more distant States and foreign countries.

On the other hand, to be contrasted with this relatively local influence, is the wider reach of the International Exchange Service, as associated with the publications of the Institution. Reviewing the whole field, Dr. Abbot is led to the conclusion that the care of the public exhibits, educational and interesting though they are, is after all not the greatest duty of the Smithsonian Institution. In his view its main services to science are :

"In the collection of new specimens, which the passage of a few more years might prevent for ever ; in the study of existing national collections to unlock the treasures of knowledge which they certainly contain; in the promotion of researches growing out of our expert experience in the field of radiation; in the publication of knowledge in both technical and popular forms ; and in the wide diffusion of knowledge through exchanges and correspondence in all these lines, activities entirely suited to the genius and situation of the Smithsonian, which in their world-wide application and future promise, outrank in value the more local influence of the public exhibitions."

The one thing that is lacking to promote these

No. 3104, VoL. 123] 
researches on the scale they deserve is, the impecunious institutes of Britain will learn with a shock of sympathy, lack of adequate means.

Put broadly, Dr. Abbot's view rather sounds like pitting against one another the advance of technical knowledge and the scientific education of the people, the latter of which is bound in the end to be more local in its development, since the less educated a person may be the more he must depend on sense impressions and the less on the mental stimulus of the written word; and the Smithsonian plumps heavily for the former. Now we are not convinced that the contrast is a necessary one, since if both the scientific education of the people and the advance of technical scientific knowledge are essential, it can scarcely be said that one is of more value than the other. Both are necessary ingredients in the sum of scientific advancement.

If science is to make the progress it deserves, it must be upon the basis of a wide sympathy and understanding amongst the plain men of the earth. At the lowest terms of this compact, research can obtain the adequate funds which the Smithsonian and every other scientific institution longs for, only when the public has grasped the vital importance of scientific results so thoroughly that it compels the disbursement for such purposes of the State funds which it itself contributes. In other words, in these democratic days, the adequate prosecution of research is inextricably bound up with the scientific education of the people.

\section{Science and Humanism.}

$\mathrm{T}$ HE neglect of science by historians, and the misunderstanding of its service by representatives of labour, are familiar to most readers of Nature. The new review The Realist, to which reference was made in our issue of April 6, p. 540, contains two contributions dealing respectively with these subjects-one by Dr. Singer on scientific humanism and the other by Mr. John Gibson on the relations of labour and science. Both describe from different points of view a state of things which our readers would wish to alter: both resolve themselves ultimately into a question of education.

Dr. Singer starts with the astounding fact, often commented on in these columns, that our accustomed books on history, even such monumental works as the "Cambridge Modern History," ignore, for the most part completely, the rôle played by science in the historic process. As he

$$
\text { No. 3104, VoL. 123] }
$$

says-and it is a new way of putting it-" Had it so fallen out that Galileo and Kepler, Newton and Lavoisier and Darwin had been Persians, Turks, Indians, and Russians instead of Italians, Germans, Frenchmen, and Englishmen, it is very certain that the face of the civilised world would have been quite different from what it is. Yet such names are wellnigh ignored in ordinary works of history." The 'ordinary' historian, when charged with this, says either that history is past politics, or how men have come to live together more or less peacefully in States, or, if he does not subscribe to this narrow and exploded heresy, that he does not know about science and thinks it better to leave it to those who do. The latter argument, however, is not applicable to such a work as the "Cambridge Modern History," which is a composite production and might just as well contain chapters on science as it does certain chapters on literature.

The right solution is one which will take years of philosophic thinking to achieve, namely, what is the place which science has taken in building up the social structure which is, as most of the historians now perceive, the proper subject of history. Dr. Singer therefore seems to us perfectly right in laying more stress on the introduction of science in its proper place in the presentation of general history than on the elaboration of the historic side in the teaching of science, though that also is a good thing.

The article by Mr. Gibson, on science and labour, is more depressing and raises another educational question of a wider kind. Mr. Gibson notes the almost complete absence of any knowledge or interest in science among the workmen whom he has met, and also finds dread and opposition to the spread of machinery as displacing the human worker. $\mathrm{He}$ is probably generalising from the class of workmen - those in the building tradeswho suffer most immediately from the introduction of new machines and have the least turn for mechanics. The picture would not be so black if it were painted of any branch of the engineers. So far as the educational question is concerned, it should be easier rather than more difficult to imbue the young workman with some knowledge and interest in science than his more lettered fellow-scholar who gives so much time to literature and the study of the dead languages. The boy who goes to a technical or a central school with an industrial bias-and these places are growinghas a good opportunity of approaching science at least on the practical side, and Mr. Gibson's account of the young man of to-day who does all 